УДК: 314.82

Кухта Мирослава Павлівна

кандидат соиіологічних наук,

Київський національний університет культури і мистецтв,

Київ, Украӥна

miroslavakukhta@gmail.com

\title{
МОДЕЛІ АКТУАЛІЗАЦІЇ СОЦІАЛЬНОГО ПОТЕНЦАЛУ ЛЮДЕЙ СТАРШОГО ВІКУ У КРАЇНАХ ЗАХОДУ
}

У статті обгрунтовується необхідність розгляду досвіду подолання негативних наслідків старіння населення в країнах Заходу. Розвинені країни зіткнулися $з$ проблемою старіння населення раніше країн, що розвиваються, зокрема й України. Моделі, що виробляються там, орієнтовані на актуалізацію соціального потенціалу людей старшого віку. Метою статті є аналіз переваг і недоліків моделей активізації соціального потенціалу людей старшого віку в країнах Заходу. Актуалізація внутрішнього соціального потенціалу старших людей може відбуватися за рахунок інституційних зусиль суспільства, або за рахунок зусиль самої групи. В оптимальному варіанті, ці два шляхи поєднуються. Проте, це відбувається лише у випадку першопочаткової доволі високої ресурсності самої групи - відповідного рівня здоров'я, матеріального забезпечення тощо, тобто збереження характеристик, притаманних групі середнього віку. У статті доводиться, що основна проблема, зокрема для українського суспільства, полягає у збереженні перспектив на кінцевому відрізку життєвого шляху. Ї̈̈ вирішення має бути зорієнтоване на профілактичний аспект програми активного старіння, оскільки у процесі старіння потрібні стратегії, спрямовані на покращення здоров'я та добробуту по досягненню старшого віку.

Ключові слова: соціальні ресурси, соціальний потенціал, теорії старіння, успішне старіння, активне старіння.

Kukhta Miroslava, Candidate of Sociology, Kyiv National University of Culture and Arts, Kyiv, Ukraine

Senior age people social potential actualization models in the countries of the West

The article grounds the need to consider the experience of overcoming the negative consequences of aging population in the countries of the West. Developed countries have faced the problem of population aging before the countries that are developing, including Ukraine. Models produced there are focused on the actualization of the older people social potential. The purpose of the article is to 
analyze the advantages and disadvantages of the models aimed at the older people social potential activation in Western countries. The actualization of the internal social potential of the older people can take place due to the society institutional efforts, or through the efforts of the group itself. In the optimal variant, these two ways are combined. However, this happens only in the case of the initially higher resource of the group itself - the corresponding level of health, material security, etc. - that is, preserving the characteristics inherent in the middle-aged group. The article proves that the main problem, in particular for the Ukrainian society, is to preserve the prospects for the final segment of the life path. Its solution should be oriented towards the precautionary aspect of the active aging program, because in the course of aging, there is a need for the strategies aimed at improving health and well-being when reaching older age.

Key words: social resources, social potential, theories of aging, successful aging, active aging.

Кухта Мирослава Павловна, кандидат сочиологических наук, Киевский национальный университет культуры и искусств, Киев, Украина

\section{Модели актуализации социального потенциала людей старшего возраста в странах Запада}

В статье обосновывается необходимость рассмотрения опыта преодоления негативных последствий старения населения в странах Запада. Развитые страны столкнулись с проблемой старения населения раньше стран, что развиваются, включая Украину. Модели, производимые там, ориентированные на актуализацию социального потенциала людей старшего возраста. Целью статьи является анализ преимуществ и недостатков моделей активизации социального потенциала людей старшего возраста в странах Запада. Актуализация внутреннего социального потенциала пожилых людей может происходить за счет институциональных усилий общества, или за счет усилий самой группы. В оптимальном варианте, эти два пути сочетаются. Однако это происходит лишь в случае изначально довольно высокой ресурсности самой группы - соответствующего уровня здоровья, материального обеспечения и т. д. - т. е. сохранения характеристик, присущих группе среднего возраста. В статье доказывается, что основная проблема, в частности для украинского общества, заключается в сохранении перспектив на конечном отрезке жизненного пути. Её решение должно быть ориентировано на предупредительный аспект программы активного старения, поскольку в процессе старения нужны стратегии, направленные на улучшение здоровья и благосостояния по достижению старшего возраста.

Ключевые слова: социальные ресурсы, социальный потенциал, теории старения, успешное старение, активное старение. 
Вступ. Соціальний потенціал на сьогоднішній час є головним ресурсом та передумовою соціального розвитку (адже не випадково індекс людського розвитку, що до 2013 р. носив назву «Індекс розвитку людського потенціалу» останнім часом слугує головним показником для оцінки та співставлення рівня життя, освіти та довголіття різних країн). Соціальний потенціал - сукупність характеристик співдіючих суб'єктів, що за певних умов, будучи актуалізованими, можуть стати ресурсом різнобічного, насамперед, соціоекономічного розвитку суспільства. Причому цей ресурс стосується i внутрішнього розвитку, тобто саморозвитку групи-носія потенціалу, і зовнішнього - розвитку за його рахунок решти соціальних груп [2].

Суттєве зміщення вікової піраміди у розвинених країнах світу в бік зростання питомої ваги старшого населення, не дозволяє закривати очі на необхідність їх фінансового та соціального забезпечення, а перспектива довшого професійного використання літніх людей, хоча б за рахунок відстрочення пенсійного віку, видається надто привабливою з багатьох позицій, аби нею нехтувати. У цьому плані дослідник С. Капіца вважає, що за сучасних умов інтенсифікації демографічного старіння, можливі два варіанти розвитку стагнація, або зростання якості життя. Демографічні зміни, за ним, вимагають адаптації економічних і соціальних інститутів до нових умов [1, с. 90].

Використання соціальних ресурсів, таким чином, виступає пріоритетним напрямом у створенні програм соціального розвитку як такого, що не лише гарантує підвищення рівня життя, проте й відкриває можливості для самореалізації, і в цьому процесі провідну роль відіграє саме старше покоління та соціально-вікова група, що здатна за рахунок набутого соціального потенціалу не тільки вирішувати власні внутрішньогрупові проблеми, а й виступати локомотивом для ін. вікових груп.

Метою статті, таким чином, виступає аналіз моделей активізації соціального потенціалу людей старшого віку в країнах Заходу.

Аналіз останніх досліджень і публікацій. На сьогоднішній день на Заході розглядаються окремі питання соціально-демографічного складу населення старшого віку, тривалість життя різних соціально-професійних груп старших, процес старіння та виходу на пенсію (Е. Россетом, П. Ласлетт, М. Янг та Т. Шуллер); зміни при переході від молодого до старшого віку (С. Ірвін); особливості вікової стратифікації (М. Райлі, М. Іонсон); особливості життя людей старшого віку (Р. Тейлор); старіння в сучасному світі (С. Мак Фаден); особливості комунікації старших людей (Дж. Ньюсбаум). Серед цілісних теорій, що виокремилися на Заході, можна назвати наступні:

- теорія субкультури для похилого віку, запропонована Е. Роузом, котрий вважає, що представники невеликих соціальних груп, що мають власну 
субкультуру, більше взаємодіють один 3 одним, аніж 3 іншою частиною суспільства. Таким чином, люди, що збираються виходити на пенсію, об'єднуються на основі спільних інтересів;

- теорія роз'єднання, обгрунтована Б. Ньюгартеном та Дж. Розеном, стверджує невідворотність обмеження спілкування старіючої людини з іншими членами суспільства, тому що з виходом на пенсію змінюються ï соціальні ролі та знижується дохід. Теорія була продовжена Е. Каммінгом та В. Генрі, котрі вказували, що роз'єднання (disengagement) $є$ психосоціальним явищем, наслідком як природних змін в психіці старіючої людини, так і впливом на неї соціального середовища;

- теорія модернізації описує зміну становища похилих людей та ставлення до них як наслідку технізації і модернізації сучасного суспільства, внаслідок чого авторитет і значення їх досвіду значно впали;

- теорія геротрансценденції - обгрунтована Л. Торнстамом, який виділив особливий вид позитивного старіння (на основі теорій К. Юнга та Е. Еріксона). За ним, старіння людини включає потенціал для розвитку та розуміння нового погляду на життя, перехід з більш раціонального та матеріального погляду на світ до більш трансцендентного, що в підсумку супроводжується збільшенням задоволеності від життя [3].

Слід сказати, що наукові теорії, пов'язані зі старінням, на сьогоднішній день переорієнтувалися 3 суто теоретичних площин розгляду до розгляду можливостей практичної реалізації для стабілізації суспільного розвитку та зниження міжпоколінної напруженості в зв'язку з навантаженням на економічно активну молодь. Ці теорії мають назву успішного та активного старіння. На перший погляд, вони відображають оптимум використання можливостей старшого віку, проте тут існують і деякі неспівпадіння.

Виклад основного матеріалу дослідження. Відправною точкою моделі успішного старіння є діяльність. До досягнення похилого віку люди повинні так керувати життям, щоб уникнути інвалідності та захворювань, i, таким чином, підтримувати психічні та фізичні можливості, що сприяють продуктивній i соціальній участі у суспільстві. Ключ до «успішного старіння» тут першопочатково бачився як продовження діяльності в літньому віці та збереження цінностей, характерних для людей середнього віку, що заперечують настання старості $[10 ; 8 ; 14]$.

Концепція, створена понад 40 років тому П. Батлером, почала швидко набувати популярності після публікації статті Дж. Роу та Р. Кана в 1987 р., де стверджувалося, що старіння та захворювання - це різні процеси. Це був важливий крок, оскільки до тих пір дослідники старіння здебільшого зосереджувалися на уявленнях про втрату та занепад, причому самі хвороби бачилися похідними старіння. Учені розробили свою початкову модель 
успішного старіння, куди включили три компоненти: низьку вірогідність захворювання та інвалідизації, пов'язаної 3 хворобами, високого рівня когнітивних і фізичних можливостей, а також активної взаємодії з навколишнім середовищем, зокрема в соціальній сфері [10].

У цій моделі, вважаємо, переоцінили поширеність людей похилого віку, що пройшли старість без хвороб, в той час, коли ряд досліджень показово свідчить, що досягнення старості без поганого здоров'я або інвалідності $\epsilon$ виключенням [9]. «Успішний» означає, що є переможці та переможені, проте більшості геронтологів незручно маркувати когось як такого, що отримав негативні результати через його погане здоров'я» [12].

Процеси визначення та вимірювання успішного старіння були доволі проблематичними, оскільки пов'язувалися, насамперед, з тим, як люди старшого віку повинні старіти, а не з тим, з яких позицій вони самі виходять, щоб віднести себе до категорії «старіючих успішно» [5]. Наприклад, навіть якщо люди похилого віку хворіють або набувають інвалідності, вони не обов'язково починають відносити себе до тих, що старіють «не успішно».

Модель активного старіння наголошує на забезпеченні прав людей похилого віку щодо збереження здоров'я (зменшення витрат на охорону здоров'я та соціальну допомогу), продовженні термінів праці (зменшення пенсійних витрат), а також участі у суспільному та політичному житті. Проте, незважаючи на широке використання, поняття активного старіння не має чіткого загальновизнаного визначення та зазвичай використовується для означення «все для всіх людей» [7]. Така неоднорідність у визначенні створює труднощі на шляху розробки та реалізації єдиної політики щодо старших, роблячи ії більш диференціальною як на міжнародному, так i національному рівнях [11]. Незважаючи на цей недолік, поняття активного старіння широко використовується протягом останніх 10 років в Європі. Це пов'язано із зусиллями Всесвітньої організації охорони здоров'я (ВОO3) та Європейської комісії (СК) [6].

Концепція активного старіння почала розвиватися в 90-х рр. 3 акцентом на зв'язок між діяльністю та здоров'ям. Вона з'явилася в той час, коли проблема глобального посилення призвела до демонтажу традиційної концепції життя, яка прирівнювала найстарішу фазу життя до бездіяльності [7]. Дискурс активного старіння зосереджується на заохоченні участі людей похилого віку в суспільстві та підкреслює компетенцію та знання, які мають люди похилого віку.

Подібно до успішного старіння, поняття активного старіння також не залишається без критики. Наприклад, деякі вчені звертають увагу на те, що процес ідеалізації активного та (успішного старіння) може стати контрпродуктивним та гнітючим. Існує небезпека того, що політики, що виробляють політику, переоцінюють фізичну активність, нехтуючи розумовими 
здібностями, і переоцінюють продуктивну модель активного старіння. Таким чином, необхідно залишати місце для альтернативного способу життя та визначення діяльності [7].

Замість того, щоб прирівнювати найстарішу фазу життя до періоду відпочинку, моделі активного та успішного старіння орієнтуються на чим довше забезпечення участі старших у суспільному виробництві. Проте, більш комплексне визначення активного старіння здається менш детермінованим як результатом, так і як процесом його досягнення. Це швидше концепція, аніж успішне старіння, що пропонує більший позитивний політичний потенціал, ніж ін. дискурси старіння [4].

Старіння перетворилося на центральну проблему європейської політики на поч. 90-х рр., коли СК створила «обсерваторію» для вивчення впливу національної політики на старіння. Перше проголошення на цьому рівні ключових елементів нового активного дискурсу зі старіння було позначено через проголошення Європейського року людей похилого віку в 1993 р. Було поставлено акцент на дискурсах гідності та включення людей похилого віку за допомогою заходів рівних можливостей. Проголошення ООН «Рік людей похилого віку 1999» - стало наступним великим кроком у розробці європейської програми дій щодо старіння населення, в якому висвітлювалася значна проблема, з якою стикається Європа.

У політичному документі «На шляху до Свропи для всіх віків» було відзначено існування чотирьох проблем: зниження чисельності населення працездатного віку; витрати на пенсійні системи та державні фінанси; зростаюча потреба у догляді за людьми похилого віку; різноманітність ресурсів і ризиків людей похилого віку. Ці виклики, в свою чергу, привели Комісію до чотирьох політичних висновків:

- підвищити рівень зайнятості в Європі (шляхом сприяння безперервному навчанню, гнучким робочим механізмам та покращенню стимулів до роботи);

- поліпшити політику соціального захисту та змінити тенденції дострокового виходу на пенсію;

- підтримувати дослідження, пов'язані 3 політикою в галузі охорони здоров’я та догляду за старінням;

- розробляти політику проти дискримінації на робочих місцях і соціальної ізоляції [6].

Однак, незважаючи на значний потенціал цієї моделі старіння, їі позиції згодом були звужені, бо зайнятість стала їі основною спрямованістю. Це досить утилітарне бачення висуває потребу у «активізації» старших працівників для посилення економічного зростання. 
В Україні проблема старіння останніми роками також загострилася. Поки що серед активних форм протидії негативним наслідкам цього процесу (що, по суті, є величезним досягненням суспільства та, водночас, великою загрозою для його економічного зростання) $є$ збільшення пенсійного віку. Звісно, українські реалії відрізняються від західних хоча б тим, що у нас старіння має дещо інші детермінанти і переважно має вигляд старіння «знизу»за рахунок високої смертності серед населення середнього віку, в той час як на Заході це старіння «зверху» - за рахунок підвищення тривалості життя. Водночас, ігнорувати досвід та стратегії, вироблені в розвинених країнах протягом десятиліть, не можна. У сучасній гонитві за ресурсами втрата активності значної і такої, що дедалі збільшується, частки населення як 3 соціальної, так і з економічної позицій, виступають марнотратством, яке неприпустиме для сучасного українського соціуму. То ж вітчизняним науковцям найближчим часом доведеться шукати аргументовану відповідь на цей виклик епохи.

Висновки. Справді, актуалізація внутрішнього соціального потенціалу старших людей може відбуватися за рахунок або ж інституційних зусиль суспільства, (в цьому випадку старша вікова група виступає об'єктом відповідних дотацій; однак щільно пов'язана з цим політика ескапізму щодо старих; по-перше, викликає спротив відносно стигм «зайвого тягаря» та «відчуженої непотрібності»; по-друге, не позбавляє старих політичного впливу і політичних прав; по-третє, у перспективі вимагатиме ще більших коштів на утримання цієї соціально вікової групи, чисельність якої зростає) або ж за рахунок зусиль самої групи. В оптимальному варіанті, ці два шляхи поєднуються. Проте це відбувається лише у випадку першопочаткової доволі високої ресурсності самої групи - відповідного рівня здоров'я, матеріального забезпечення тощо, тобто збереження характеристик, притаманних групі середнього віку.

Проблема, зокрема для українського суспільства, полягає у збереженні перспектив на кінцевому відрізку життєвого шляху. Ї̈̈ вирішення має бути зорієнтоване на профілактичний аспект програми активного старіння, оскільки в процесі старіння потрібні стратегії, спрямовані на покращення здоров'я та добробуту по досягненню старшого віку. Нова активна парадигма старіння, спрямована на полегшення збереження як фізичних, так і розумових здібностей, грунтується на наданні можливостей літнім людям працювати довше, а також забезпечити більш здорові та більш продуктивні роки після закінчення робочого життя. 


\section{Список використаних джерел:}

1. Капица С. П. Демографическая революция и будущее человечества / С. П. Капица // В мире науки. - 2004. - № 4. - С. 90.

2. Кухта М. Соціальний потенціал старшого покоління як ресурс суспільного розвитку / М. Кухта // Габітус, Причорномор. наук.-дослід. ін-т екон. та інновацій. - 2017. - Вип. 4. - С 60-65.

3. Кухта М. Люди похилого віку очима експертів: труднощі та шляхи подолання життєвих негараздів / М. Кухта // Соціологія: теорія, методи, маркетинг: наук.-теорет. часоп. / Ін-т соціології НАН України, 2015 - № 4. C. 119-133.

4. Barrett G. Narratives of (in) active ageing in poor deprived areas of Liverpool / G. Barrett, C. McGoldrick // International Journal of Sociology and Social Policy, 2013 - Vol. 33. - P. 347-366.

5. Chapman S. Theorizing about aging well: Constructing a narrative [Electronic recource] / S. Chapman // Canadian Journal on Aging, 2005. - Vol. 24. P. 9-18. - Mode of access: https://www.ncbi.nlm.nih.gov/pubmed/15838822. - Last access: 20.01.2018. - Title from the screen.

6. European Commission (EC). Towards a Europe for all ages [Electronic recource] // Promoting Prosperity and Intergenerational Solidarity. - Brussels, 1999. Mode of access: http://ec.europa.eu/employment_social/social_situation/docs/com221_en.pdf/. - Last access: 20.01.2018. - Title from the screen.

7. Foster L. Active and Successful Aging [Electronic recource]: A European Policy Perspective / Liam Foster, Alan Walker // Gerontologist. - 2015. - № 55 (1). P. 83-90. Mode of access: https://www.ncbi.nlm.nih.gov/pmc/articles/PMC4986585/. - L Last access: 20.01.2018. - Title from the screen.

8. Havighurst R. Successful Ageing / R. Havighurst // Processes of aging: Social and psychological perspectives. - New York: Atherton, 1963. - Vol. 1. P. 299-320.

9. Motta M. Successful aging in centenarians: myths and reality / M. Motta, E. Bennati L. Ferlito, M. Malaguarnera, L. Motta // Italian Multicenter Study on Centenarians (IMUSCE). - Arch. Gerontol. Geriatr. - 2005. - № 40 (3). - P. 241-251.

10. Rowe J. Human Ageing Usual and Successful / J. Rowe, R. Kahn // Science, 1987. - Vol. 237. - P. 143-149.

11. Sidorenko A. Active ageing in CIS countries: Semantics, challenges and responses [Electronic recource] / A. Sidorenko, A. Zaidi // Current Gerontology and Geriatrics Research, 2013. - Vol. 1. P. 10-11. - Mode of access: https://www.ncbi.nlm.nih.gov/pmc/articles/PMC3549383/. _ _ Last access 22.01.2018. - Title from the screen. 
12. Strawbridge W. Active Aging and Successful Aging / W. Strawbridge // Journal of Aging and Health, 2002. - Vol. 24 (8). - P. 1279-1297.

13. Walker A. Active Ageing: A strategic policy solution to demographic ageing in the European Union / A. Walker, T. Maltby // International Journal of Social Welfare, 2012. - Vol. 17 - P. 117-130.

14. Walker A. A Strategy for Active Ageing [Electronic recource] / A. Walker // International Social Security Rewiew, 2002. - Vol. 55 (1). - P. 121-140. - Mode of access:

https://is.muni.cz/el/1423/podzim2013/SOC570/um/Walker_Strategy_for_AA_2002. pdf. - Last access: 22.01.2018. - Title from the screen.

\section{References}

1. Kapitsa, S.P. (2004). Demographic revolution and the future of mankind. $V$ mire nauki [In the world of science], no. 4, P. 90.

2. Kukhta, M. (2017). Social potential of the older generation as a resource of social development. Habitus: Prychornomorskyi naukovo-doslidnyi instytut ekonomiky ta innovatsii [Gabitus: Black Sea Research Institute of Economics and Innovation], issue 4, pp. 60-65.

3. Kukhta, M. (2015). Older people by the eyes of experts: difficulties and ways to overcome life's disadvantages. Sotsiolohiia: teoriia, metody, marketynh. Naukovo-teoretychnyi chasopys - Instytut Sotsolohii NAN Ukrainy [Sociology: theory, methods, marketing. Scientific and Theoretical Journal - Institute of Sociology of the National Academy of Sciences of Ukraine], no. 4, pp. 119-133.

4. Barrett, G., McGoldrick, C. (2013). Narratives of (in) active ageing in poor deprived areas of Liverpool. International Journal of Sociology and Social Policy, Vol. 33, pp. 347-366.

5. Chapman, S. (2005). Theorizing about aging well: Constructing a narrative. Canadian Journal on Aging, Vol. 24, pp. 9-18 [online] Available at: https://www.ncbi.nlm.nih.gov/pubmed/15838822. [Accessed 20 January 2018]. Title from the screen.

6. The European Commission (EC). (1999). Towards a Europe for all ages. Promoting Prosperity and Intergenerational Solidarity. Brussels [online] Available at: http://ec.europa.eu/employment_social/social_situation/docs/com221_en.pdf/. [Accessed 20 January 2018]. Title from the screen.

7. Foster, L. (2015). Active and Successful Aging: A European Policy Perspective. Gerontologist, issue 55(1), pp. 83-90 [online] Available at: https://www.ncbi.nlm.nih.gov/pmc/articles/PMC4986585/. [Accessed 20 January 2018]. Title from the screen.

8. Havighurst, R. (1963). Successful Ageing. Processes of aging: Social and psychological perspectives, New York, Atherton, Vol.1, pp. 299-320. 
9. Motta, M., Bennati, E., Ferlito, L., Malaguarnera, M., Motta, L. (2005). Successful aging in centenarians: myths and reality. Italian Multicenter Study on Centenarians (IMUSCE), Arch. Gerontol. Geriatr, issue May-Jun.40(3), pp.241-251.

10. Rowe, J., Kahn, R. (1987). Human Ageing Usual and Successful. Science, Vol. 237, pp. 143-149.

11. Sidorenko, A., Zaidi, A. (2013). Active ageing in CIS countries: Semantics, challenges and responses. Current Gerontology and Geriatrics Research, Vol. 1, pp. 10-11 [online] Available at: https://www.ncbi.nlm.nih.gov/pmc/articles/PMC3549383/. [Accessed 22 January 2018]. Title from the screen.

12. Strawbridge, W. (2002). Active Aging and Successful Aging. Journal of Aging and Health, Vol. 24 (8), pp.1279-1297.

13. Walker, A., Maltby, T. (2012). Active Ageing: A strategic policy solution to demographic ageing in the European Union. International Journal of Social Welfare, Vol.17, pp. 117-130.

14. Walker, A. (2002). A Strategy for Active Ageing. International Social Security Rewiew, Vol. 55 (1), pp. 121-140 [online] Available at: https://is.muni.cz/el/1423/podzim2013/SOC570/um/Walker_Strategy_for_AA_2002. pdf. [Accessed 20 January 2018]. Title from the screen.

(C) Кухта М. П., 2018 